\title{
ANALISIS STRATEGI MARKETING LAYANAN PAYROLL (Studi Kasus Bank BNI Syariah KCP Jababeka-Cikarang)
}

\author{
Riski Eko Ardianto ${ }^{1}$, Listian Indriyani Achmad ${ }^{2}$, Ria Kurniawati ${ }^{3}$ \\ 1 Universitas Pelita Bangsa, rizkyardhy@gmail.com \\ 2 Universitas Pelita Bangsa, listian.achmad@pelitabangsa.ac.id \\ ${ }^{3}$ Universitas Pelita Bangsa, riakurniawati41@gmail.com
}

\section{A R T I C L E I N F O}

\section{Article history:}

Received : 28/03/2021

Revised : 29/03/2021

Accepted: 05/04/2021

Key words:

Analysis; strategy; marketing; Payroll Service; BNI Syariah.

\section{DOI:}

Doi.org/10.37366/jespb.v6i01.178

\section{A B S T R A C T}

In recent years, Islamic banking has experienced positive developments. With a situation like this, conventional banking will face new competition with the presence of Islamic banks. The competition is in its products, one of which is a payroll service product that can help a companies or institutes pay its employees en masse and efficiently at one time. At this time not only conventional banks have payroll service products, Islamic banks also have payroll service products that can meet the needs of companies or institutes in managing finances whose operating processes are adjusted to Islamic sharia principles.

This study aims to determine the marketing strategies implemented in BNI Syariah, know the concept of the system of marketing payroll service product in BNI Syariah KCP Jababeka-Cikarang and find out obstacles faced by BNI Syariah in implementing the marketing the market strategy of its products. This study uses a qualitative approach, namely field research and library research. Field research, namely data collection techniques with the method of observation, interviews and documentation with marketing staff and customers of BNI Syariah KCP JababekaCikarang so as to get accurate data in the research process. And library research, namely data collection techniques using written sources.

Through interviews and observation it can be seen that the marketing strategy carried out by BNI Syariah KCP Jababeka-Cikarang in marketing their Payroll Service products is by using the Marketing Mix 7P (Product, Price, Place, Promotion, People, Process, Physical Evidance), and the concepts applied in its marketing in the form of needs, wants, demands, products, value, costs, satisfaction, exchange and markets. And the type of payroll system used is BNIDirect which is one of a number of financial management service provided by BNI Syariah KCP Jababeka-Cikarang.

\section{A B S T R A K}

Dalam beberapa tahun terakhir, perbankan syariah mengalami perkembangan yang positif. Dengan situasi seperti ini, perbankan konvensional akan menghadapi persaingan baru dengan hadirnya bank syariah. Yang menjadi persaingannya adalah dalam produk-produknya, salah satunya adalah produk jasa layanan payroll yang dapat membantu perusahaan atau institut dalam penggajian karyawannya secara masal dan efisien dalam satu waktu. Pada saat ini tidak hanya bank konvensional saja yang memiliki produk jasa layanan payroll, bank syariah juga memiliki produk jasa layanan payroll yang dapat memenuhi kebutuhan perusahaan atau isntitut dalam mengelola keuangan yang proses pengoperasiannya disesuaikan dengan prinsip Syariah Islam.

Penelitian ini bertujuan untuk mengetahui strategi marketing yang diterapkan di BNI Syariah, mengetahui konsep sistem dari pemasaran produk Layanan Payroll di BNI Syariah KCP Jababeka-Cikarang, dan untuk mengetahui hambatan yang dihadapi PT. Bank BNI Syariah dalam menerapkan strategi marketing produk-produknya. Penelitian ini menggunakan pendekatan 
penelitian kualitatif yaitu penelitian lapangan dan penelitian kepustakaan. Penelitian lapangan yaitu teknik pengumpulan data dengan metode observasi, wawancara dan dokumentasi dengan staff marketing dan nasabah BNI Syariah KCP Jababeka-Cikarang, sehingga mendapatkan data yang akurat pada proses penelitian. Dan penelitian kepustakaan, yaitu teknik pengumpulan data dengan menggunkan sumber tertulis.

Melalui wawancara dan observasi dapat diketahui bahwa strategi marketing yang dilakukan BNI Syariah KCP Jababeka-Cikarang dalam memasarkan produk jasa Layanan Payroll mereka yaitu dengan menggunakan Strategi Marketing Mix 7P, (Product, Price, Place, Promotion, People, Process, Physical Evidance) dan konsep yang diterapkan dalam sistem Layanan Payroll menggunakan sistem BNIDirect yang merupakan satu dari sejumlah layanan pengelolaan keuangan yang disediakan oleh BNI Syariah. Dan hambatan yang dihadapi oleh PT. BNI Syariah KCP Jababeka-Cikarang dalam menerapkan strategi marketing produk Layanan Payroll.

\section{PENDAHULUAN}

Dalam kehidupan perbankan, pemasaran memainkan peranan yang sangat penting dalam keberhasilan suatu perusahaan. Hal ini didasari karena semakin ketatnya persaingan bisnis dalam dunia perekonomian. Perkembangan perbankan syariah yang begitu cepat tentu harus diikuti dengan peningkatan strategi terutama bagian pemasaran yang merupakan pelaku paling depan dalam operasional bank syariah (Wiroso, 2005:1). Perbankan merupakan salah satu agen pembangunan (agent of development) dalam kehidupan bernegara, karena fungsi utama dari perbankan adalah sebagai lembaga intermediasi keuangan (financial intermediary institution), yaitu lembaga yang menghimpun dana dari masyarakat dalam bentuk simpanan dan menyalurkan kembali kepada masyarakat dalam bentuk kredit atau pembiayaan (Muhammad, 2012:2).

Bank di Indonesia terbagi menjadi dua jenis yaitu, bank yang bersifat konvensional dan bank yang bersifat syariah. Bank yang bersifat konvensional adalah bank yang kegiatan operasionalnya menggunakan sistem bunga, sedangkan bank syariah adalah bank yang kegiatan operasional dan produknya dikembangkan berlandasan Al-Qur'an dan Hadits. Dengan kata lain, bank syariah atau perbankan Islam adalah lembaga keuangan yang berfungsi sebagai penghimpun dan penyalur dana dari masyarakat untuk masyarakat, dimana sistem operasionalnya sesuai dengan syariat Islam (Karim, 2006:2). Adapun dalam tata cara bermuamalat secara Islam tersebut dijauhi dari segala praktek yang dikhawatirkan mengandung unsur-unsur riba untuk diisi dengan berbagai kegiatan investasi atas dasar bagi hasil dan pembiayaan perdagangan (Purwaatmatdja \& Antonio, 1992: 2). Pendanaan atau penghimpunan dana di bank syariah dapat berbentuk tabungan, deposito dan giro. Pembiayaan adalah usaha bank dalam menyalurkan dananya kepada nasabah dengan tujuan penggunaan prinsip jual-beli, sewa, bagi hasil dan akad pelengkap. Selain itu bank syariah memberikan pelayanan jasa perbankan kepada nasabah yang imbalannya berupa sewa atau keuntungan (Wirdyaningsih, 2005:61).

Perbankan syariah dikenal sebagai Islamic Banking, yang pada awalnya dikembangkan sebagai suatu respon dari kelompok ekonomi dan praktisi yang berlingkup syariah. Sejak adanya revisi UU No. 10 Tahun 1998 tentang Perbankan, terdapat beberapa perubahan yang memberikan peluang yang lebih besar bagi pengembangan perbankan syariah. Dari UU tersebut menerangkan bahwa sistem perbankan syariah dikembangkan dengan beberapa tujuan yakni memenuhi kebutuhan jasa perbankan bagi masyarakat yang tidak menerima konsep bunga, memenuhi kebutuhan akan produk dan jasa perbankan yang memiliki beberapa keunggulan komparatif berupa peniadaan 
pembebanan bunga, membuka peluang pembiayaan bagi pengembangan usaha berdasarkan prinsip kemitraan dengan menjaga hubungan investor yang harmonis. Sementara pada bank konvensional konsep yang diterapkan adalah hubungan debitur dan kreditur. Perbankan syariah berusaha mengakomodir pihak yang menginginkan adanya jasa transaksi keuangan yang berjalan sesuai dengan prinsip-prinsip syariah, agar terhindar dari pelanggaran praktek riba, kegiatan yang sifatnya serupa dengan perjudian, gharar (ketidakpastian) dan pelanggaran prinsip terhadap transaksi (Sudarsono, 2003:25).

Dikarenakan adanya nilai positif dalam penerimaan masyarakat akan penerapan nilai-nilai syariah, pada tanggal 29 April 2000 didirikan Unit Usaha Syariah (UUS) BNI dengan 5 kantor di Yogyakarta, Malang, Pekalongan, Jepara, dan Banjarmasin. Selanjutnya UUS BNI terus berkembang menjadi 28 kantor cabang dan 31 kantor cabang pembantu. Berdasarkan keputusan Gurbernur Bank Indonesia Nomor 12/41/KEP.GBI/2010 tanggal 21 Mei 2010 mengenai pemberian izin usaha kepada PT. Bank BNI Syariah. Maka dari tanggal 19 Juni 2010 PT. Bank BNI Syariah secara resmi beroperasi. Dengan berdirinya Bank BNI syariah mendorong pertumbuhan bisnis yang lebih agresif dengan disertai oleh peningkatan kualitas layanan dan terus melakukan inovasi agar dapat menjadi pemimpin di industri perbankan syariah. Dalam jangka panjang, strategi bisnis diarahkan untuk mencapai tiga tujuan utama yaitu optimalisasi profit dalam rangka memaksimalkan nilai bagi pemegang saham, menjaga kesinambungan pertumbuhan bisnis, dan berkontribusi aktif terhadap kehidupan masyarakat dan kelestarian lingkungan (Company Profile BNIS, 2014:42).

Bank BNI Syariah meliputi berbagai produk yang sesuai dengan keragaman kebutuhan masyarakat Indonesia. Salah satunya adalah produk Cash Management yang dapat memenuhi kebutuhan perusahaan dalam pengelolaan keuangan. Cash Management memiliki dua fitur payment yaitu payroll management dan bulk payment. Payroll management adalah layanan untuk pemberian gaji karyawan perusahaan atau institut secara masal, tepat waktu, akurat dan proses berjalan dengan efisien. Sedangkan Bulk Payment adalah layanan yang membantu perusahaan untuk melakukan pembayaran kewajiban pada rekan bisnis dan proses penyelesaian tagihan yang dapat berjalan secara tepat waktu pada saat kewajiban jatuh tempo. Bulk payment dan payroll sistemnya hampir sama yang membedakannya yaitu bulk payment hanya membayar kewajiban dan tagihan pada sejumlah rekan bisnis yang transaksinya secara masal sedangkan payroll membayar kewajiban, tagihan dan tunjangan pada karyawan perusahaan yang berjumlah banyak yang transaksinya dengan cara masal dan tepat waktu. (PT. BNI Tbk. 2020).

Sistem payroll memudahkan pekerjaan rutin staff HRD setiap bulannya dalam menghitung gaji yang harus dibayarkan dan dihitung berdasarkan gaji pokok, transport, uang makan, uang lembur dan tunjangan lainnya yang diberikan oleh pihak perusahaan. Payroll ini bagi bank dapat digunakan sebagai upaya peningkatan produk-produknya, seperti meningkatkan jumlah nasabah yang membuka rekening, pembiayaan yang pelunasannya yang menggunakan potongan gaji payroll, sebagai perluasan bisnis dan meningkatkan citra bank (Ervina, 2020).

Menurut Direktur Bisnis PT Bank BNI Syariah Dhias Widhiyati mengungkapkan bahwa segmen bisnis layanan payroll menunjukan tren peningkatan dari waktu ke waktu. Nilai pengelolaan gaji pegawai institut kelembagaan baik kementerian, BUMN, dan Perguruan Tinggi oleh BNI Syariah saat ini berkisar Rp100 miliar perbulan. Tren pembayaran gaji karyawan melalui BNI syariah semakin meningkat seiring kenaikan DPK (dana pihak ketiga) BNI Syariah termasuk di dalamnya tabungan payroll per November 2018 sebesar 19,18\%. Hal ini dibuktikan dengan semakin banyaknya institut kelembagaan seperti kementrian, BUMN, dan Perguruan Tinggi yang telah mempercayakan BNI Syariah sebagai bank mitra pembayaran gaji (Ropesta Sitorus, 2019).

Manfaat dari Layanan Payroll ini adalah memudahkan karyawan/nasabah yang bekerja sama dengan bank, bisa dengan mudah mengambil 
gaji di ATM manapun dan langsung bisa menyimpan uang di bank tanpa harus pergi ke bank. Dan untuk lembaga/perusahaannya sendiri menjadi lebih mudah memberikan gaji kepada para karyawan karena sistem penggajiannya menggunakan layanan transaksi platform internet banking sehingga memudahkan staf HRD atau staff keuangan dalam mengatur keuangannya. Dengan adanya payroll, karyawan akan merasa aman karena hasil gaji yang didapat diterima dengan tepat waktu dan tidak dalam bentuk uang tunai melainkan tersimpan dalam data kartu ATM bank, sehingga meminimalisir terjadinya tindak kriminal.

Bank BNI Syariah menilai bahwa segmen bisnis payroll merupakan salah satu fokus non perseroan. Pasalnya selain dapat mendongkrak pertumbuhan pendapatan, layanan payroll ini merupakan pintu masuk untuk menyalurkan pembiayaan. Meningkatkan kepercayaan masyarakat/publik untuk mendapatkan layanan payroll lewat perbankan syariah menjadi salah satu pendorong kinerja Bank BNI Syariah. Jasa Layanan Payroll ini termasuk dalam akad Wakalah, yaitu penyerahan, pendelegasian atau pemberian mandate (Antonio, 2001:120). Bisa juga diartikan sebagai pelimpahan kewenangan/kuasa untuk melakukan tindakan kepada orang lain yang sesuai dengan syariah dan kesepakatan yang telah ditentukan oleh kedua belah pihak untuk melakukan suatu tindakan tertentu. Dalam layanan payrollnya sendiri, BNI Syariah menggunakan akad Wadi'ah dalam pelaksanaannya. Akad Al-Wadiah adalah transaksi pemberian mandat dari seseorang yang menitipkan suatu benda kepada orang lain untuk dijaganya sebagaimana semestinya. Dalam bisnis modern akad Wadi'ah berkaitan dengan penitipan modal, baik berupa tabungan, giro, maupun deposito (Nawawi, 2017:206).

Dalam perjalanan bisnis, BNI Syariah perlu upaya untuk mempertahankan nasabah lama dan menawarkan produk kepada calon nasabah. BNI Syariah mulai mempromosikan produk jasa layanan payroll ini dengan gabung promo fitur dan berbagai strategi yang dapat menarik perhatian konsumennya. Untuk menarik konsumen yang lebih luas diperlukan strategi marketing yang tepat sehingga layanan payroll tersebut bisa lebih dikenal oleh masyarakat terutama para pengusaha atau institut. Strategi marketing merupakan bagian integral dan strategi bisnis yang memberikan semua fungsi manajemen suatu perusahaan/organisasi/lembaga. Strategi marketing adalah cara yang akan digunakan untuk penyaluran produk atau barang yang siap untuk diterima oleh konsumen. Serta cara menarik konsumen agar membeli produk atau barang yang dipasarkan (Kasmir, 2004:201).

BNI Syariah yang sudah termasuk kategori eksistensi, maka Bank BNI Syariah mempunyai strategi khusus mempertahankan dan menambahkan nasabahnya dan mendapatka kepercayaan nasabahnya. Strategi marketing yang sesuai dengan prinsip operasioanal yang mengacu pada prinsip-prinsip syariah, terutama produk yang banyak diminati di pasaran sehingga dapat bersaing di pasaran dengan bank-bank lainnya baik itu bank konvensional atau bank syariah lain. BNI Syariah dapat bersaing dengan bank-bank tersebut melalui produk-produknya yang ditawarkan, salah satunya produk jasa Layanan Payroll. Melihat dari letak Bank BNI Syariah KCP Jababeka-Cikarang yang cukup potensial dan strategis sehingga mudah dijangkau oleh masyarakat.

\section{Rumusan Masalah}

Berdasarkan uraian pada latar belakang yang telah dijabarkan di atas, maka penulis merumuskan masalah sebagai berikut:

1) Bagaimana strategi marketing pada Layanan Payroll yang diterapkan di Bank BNI Syariah?

2) Bagaimana konsep sistem marketing dalam Layanan Payroll BNI Syariah KCP JababekaCikarang?

3) Apa hambatan yang di hadapi dalam menerapkan strategi marketing di Bank BNI Syariah KCP Jababeka-Cikarang? 


\section{Tujuan Penelitian}

Berdasarkan rumusan masalah di atas, maka penelitian ini bertujuan sebagai berikut:

1) Untuk mengetahui strategi marketing pada Layanan Payroll yang diterapkan di Bank BNI Syariah.

2) Untuk mengetahui konsep sistem marketing dalam Layanan Payroll di BNI Syariah KCP Jababeka-Cikarang.

3) Untuk mengetahui hambatan yang dihadapi dalam menerapkan strategi marketing di Bank BNI Syariah KCP Jababeka-Cikarang.

\section{TINJAUAN TEOIRITIS}

\section{Strategi Marketing}

Strategi marketing adalah logika pemasaran yang dilakukan dengan harapan bahwa unit bisnis akan mencapai tujuan dan sasaran pemasaran. Strategi marketing terdiri dari strategi spesifik untuk pasar sasaran, penentuan posisi produk, bauran pemasaran dan tingkat pengeluaran pemasaran (Kotler dan Amstrong, 2001:54). Strategi marketing pada dasarnya adalah rencana yang menyeluruh, terpadu dan menyatu dibidang pemasaran yang memberikan panduan tentang kegiatan yang akan dijalankan untuk dapat mencapai tujuan marketing suatu perusahaan. Dengan kata lain strategi marketing adalah serangkaian tujuan dan sasaran, kebijakan dan aturan yang memberi arah kepada usaha-usaha pemasaran perusahaan dari waktu ke waktu, pada masing-masing tingkatan dan acuan serta alokasinya. Terutama sebagai tanggapan perusahaan dalam menghadapi lingkungan dan keadaan persaingan yang selalu berubah-ubah. Oleh karena itu, penentuan strategi marketing harus didasarkan pada analisis keunggulan dan kelemahan perusahaan, serta analisis kesempatan dan ancaman yang dihadapi perusahaan dari lingkungannya (Sofyan, 2015:168).
Tiga langkah utama yang diperlukan bagi pemasaran dalam rangka menyediakan kerangka kerja yang lebih luas bagi keberhasilan strategi dalam pasar, yaitu:

1) Segmentasi pasar

2) Penetapan pasar sasaran

3) Menentukan posisi pasar

\section{Strategi Marketing Islami}

Marketing menurut perspektif Islam adalah suatu disiplin bisnis strategi yang sesuai dengan nilai dan prinsip syariah. Jadi marketing Islami dijalankan berdasarkan konsep ke Islaman yang sudah dianjurkan oleh Nabi Muhammad Saw. Menurut Hermawan Kertajaya, nilai inti dari marketing Islam adalah integritas dan transparan, sehingga tidak boleh berbohong dan orang membeli karena butuh dan sesuai dengan keinginan, bukan karena diskonnya atau atas iming-iming hadiah berkala. Secara umum marketing Islami adalah sebuah disiplin bisnis strategi yang mengarahkan proses penciptaan, penawaran dan perubahan value dari inisiator kepada stakeholder yang dalam seluruh prosesnya sesuai dengan akad dan prinsip-prinsip muamalah dalam Islam. Artinya dalam marketing Islam, seluruh proses baik proses penciptaan, proses penawaran maupun proses perubahan nilai tidak boleh ada yang bertentangan dengan prinsipprinsip syariah.

\section{Payroll}

Payroll adalah sistem penggajian karyawan secara masal, yang intensitasnya banyak dibutuhkan oleh perusahaan. Layanan Payroll adalah layana untuk pemberian gaji karyawan perusahaan atau institut yang bekerja sama dengan bank. Dalam hal ini menghitung gaji yang harus dibayarkan dan dihitung berdasarkan gaji pokok, tunjangan transport, uang makan, uang lembur, dan tunjangan lain yang diberikan oleh pihak perusahaan. Layanan payroll berada dalam produk Cash Management yang berakad al-wakalah. Dan dalam layanan payroll itu sendiri terdapat dua akad, yaitu akad al-mudharabah dan akad al-wadi'ah. 


\section{Kerangka Pikir}

Untuk menggambarkan penjabaran dari latar belakang penelitian ini dapat dituangkan dalam kerangka pemikiran sebagai berikut:

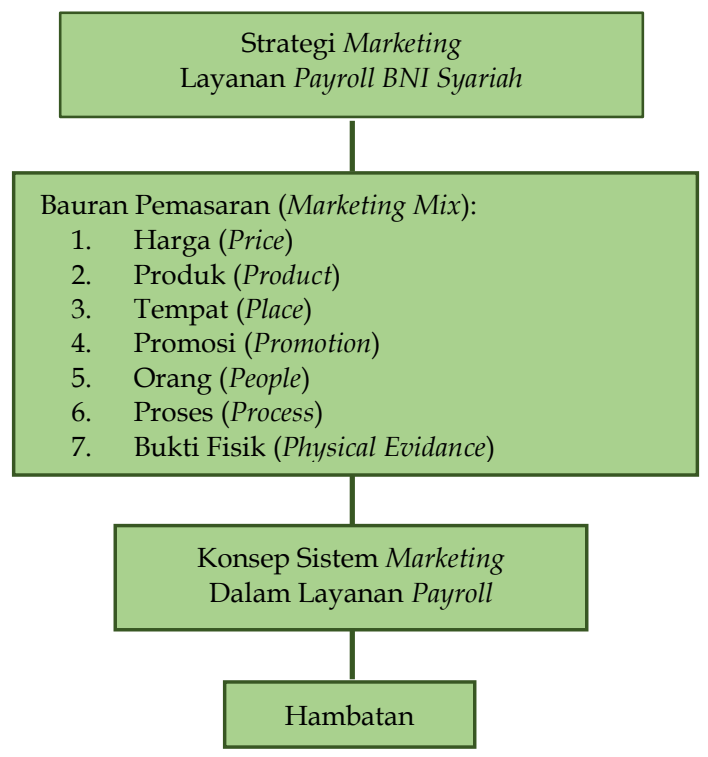

Gambar 1. Kerangka Pikir

\section{METODE PENELITIAN}

Penelitian ini menggunakan pendekatan penelitian kualitatif yaitu penelitian lapangan dan penelitian kepustakaan. Penelitian lapangan yaitu teknik pengumpulan data dengan metode observasi, wawancara dan dokumentasi dengan staff marketing dan nasabah BNI Syariah KCP Jababeka-Cikarang. Dengan demikina data yang digunakan pada penelitian ini menggunakan data primer yang didapatkan langsung dari narasumber dan data sekunder yang didapatkan dari laporan keuangan tahunan BNI Syariah serta buku/jurnal penelitian sebagai informasi pendukung. Dan tempat penelitian sebagai populasi penelitian adalah BNI Syariah KCP Jababeka-Cikarang yang beralamat di Jl. Niaga Raya Pasirsari Ruko CDB Kav.AA3 Blok CD No. 1 Cikarang Selatan, Bekasi.

\section{HASIL DAN PEMBAHASAN}

\section{Strategi Marketing Bank BNI Syariah}

Dari data yang didapatkan langsung selama proses penelitian dari lapangan dan dari pengumpulan informasi dan data-data yang terkait dari berbagai sumber yang mendukung penelitian, maka analisis yang didapatkan penulis bahwa Bank BNI Syariah Kantor Cabang Pembantu (KCP) Jababeka-Cikarang dalam memasarakan produkproduknya telah menerapkan teori dari strategi bauran pemasaran (marketing mix). Dari hasil wawancara dan penelitian dengan salah satu karyawan BNI Syariah bagian pemasaran (marketing), Bank BNI Syariah Kantor Cabang Pembantu (KCP) Jababeka-Cikarang menerapkan konsep dari bauran pemasaran dengan pendekatan 7P. yaitu:

1) Strategi Produk (Product)

Pada setiap produk yang dikeluarkan Bank BNI Syariah tidak selalu mendapatkan respon yang baik dari masyarakat. Adakalanya keberhasilan yang didapat lebih kecil dari kegagalan yang dialami. Untuk menghindari hal itu, maka Bank BNI Syariah perlu menerapkan strategi pemasaran yang tepat disetiap produknya agar mendapatkan respon yang baik dari masyarakat dan mendapat keberhasilan dari setiap produk yang dikeluarkan sesuai dengan tujuan yang diharapkan. Oleh sebab itu dalam menentukan produk yang akan ditawarkan, sebaiknya bank terlebih dahulu melakukan pengelompokan produk berdasarkan fungsi, pelayanan, target konsumen, dan target pasar.

Dalam penerapan strategi produk dalam memasarkan produk jasa Layanan Payroll atau sistem penggajian karyawan secara masal dalam satu waktu yang dilakukan Bank BNI Syariah Kantor Cabang Pembantu (KCP) Jababeka-Cikarang adalah dengan menawarkan kemudahan, manfaat, keunggulan dan keamanan dari produk jasa dan layanan payroll yang dimiliki oleh Bank BNI Syariah sehingga dapat melengkapi target pasar. Dengan keunggulan-keunggulan yang dimiliki dalam produk layanan payroll, Bank BNI Syariah Kantor Cabang Pembantu (KCP) Jababeka-Cikarang selalu berusaha menyediakan dan memberikan berbagai produk dan layanan perbankan yang dibutuhkan di kehidupan masyarakat.

Kemudahan yang ditawarkan oleh Bank BNI Syariah salah satunya adalah memperlancar dan mempermudah proses penggajian atau pemberian upah kerja untuk karyawan, karena transaksi dapat dilakukan secara elektronik melalui BNIDirect, dan 
kemudahan lainnya memberikan kepastian pembayaran dan kerahasiaan data gaji karyawan. Produk yang ditawarkan kepada calon nasabah atau mitra bisnis di Bank BNI Syariah ini dirasa telah mampu untuk ikut bersaing dengan bank atau lembaga keuangan lainnya yang ada di sekitar kota Jababeka. Hal ini dapat dilihat dari perkembangan masyarakat yang bergabung dan menjadi nasabah dan mitra bisnis di dengan Bank BNI Syariah Kantor Cabang Pembantu (KCP) Jababeka-Cikarang.

Berdasarkan hasil wawancara yang dilakukan penulis, terdapat beberapa perbedaan dari produk Layanan Payroll yang ada di Bank BNI Syariah Kantor Cabang Pembantu (KCP) Jababeka Cikarang dengan bank lainnya yaitu:

- Bebas biaya administrasi

- Bebas biaya profisis yaitu biaya yang dibebankan kepada kreditur atau nasabah atas jasa bank yang telah menyetujui pinjaman nasabah yang diajukan sebelumnya

- Proses mudah dan cepat.

- Angsuran flat

- Aman dari riba

Dari penjelasan di atas dapat ditarik kesimpulan bahwa strategi produk yang di tawarkan oleh Bank BNI Syariah Kantor Cabang Pembantu (KCP) Jababeka-Cikarang adalah dengan menampilkan kemudahan, kemanan, dan keunggulankeunggulan yang ada di dalam produk dan layanan yang diluncurkan dan ditawarkan kepada masyarakat bertujuan untuk menarik minat masyarakat agar menggunakan produk-produk dan layanan yang ditawarkan oleh Bank BNI Syariah Kantor Cabang Pembantu (KCP) Jababeka-Cikarang dan menjadi nasabah dan mitra bisnis di Bank BNI Syariah Kantor Cabang Pembantu (KCP) JababekaCikarang.

\section{2) Strategi Harga (Price)}

Penentuan dari harga produk termasuk dalam salah satu aspek penting dalam kegiatan marketing. Harga merupakan satu-satunya unsur bauran pemasaran (markrting mix) yang mendatangkan pemasukan atau pendapatan bagi bank. Disamping itu harga produk merupakan unsur bauran pemasaran (marketing mix) yang bersifat fleksibel, artinya dapat diubah-ubah dengan cepat. Bila harga produk terlalu mahal, maka produk tersebut akan tidak terjangkau oleh target pasar tertentu atau bahkan tingkat kepuasan pelanggan/nasabah menjadi rendah. Sebaliknya, jika harga produk terlalu murah bank akan sulit mendapatkan laba atau sebagian masyarakat menilai kualitas dari produk tersebut buruk. Oleh sebab itu, penetapan harga secara tepat merupakan faktor yang penting dalam menentukan kesuksesan bank dalam jangka pendek dan jangka panjang.

Dari hasil wawancara dengan salah satu karyawan Bank BNI Syariah Kantor Cabang Pembantu (KCP) Jababeka-Cikarang, strategi harga yang diterapkan oleh Bank BNI Syariah dalam memasarkan produk jasa layanan payroll dan produk-produknya yaitu dengan memberi kesan nyaman, aman dan mudah dengan harga terjangkau sesuai dengan kebutuhan masyarakat. Penetapan dari harga produk disesuaikan dengan kesepakatan antara nasabah dan pihak bank. Dimana harga itu dilihat dan disesuaikan dengan kemampuan membayar dari pihak nasabah. Penerapan harga dilakukan secara transparan, penetapan margin pada produk Layanan Payroll dengan biaya minimum Rp. 100.000,- dan dengan minimum keanggotaan 5 atau 10 karyawan disetiap lembaga atau perusahaan.

\section{3) Strategi Tempat (Place)}

Pemilihan lokasi yang tepat akan berdampak cukup signifikan terhadap penjualan terutama perusahaan yang bergerak dibidang jasa khususnya perbankan. Sehingga BNI Syariah KCP Jababeka Cikarang memilih tempat dikawasan perkantoran, tepatnya di Ruko CBD Blok/Kav. AA3 Blok CD No.1, Jl. Niaga Raya Kel. Pasir Sari, Kec. Cikarang Selatan Kab. Bekasi Jawa Barat.

Dalam meningkatkan kegiatan pemasaran dari produk dan layanan Bank BNI Syariah KCP Jababeka-Cikarang juga didukung dengan waktu operasional dan letak dari lokasi kantor yang strategis. Terdapat banyak keunggulan jika di lihat dari tempat alokasinya yaitu: lokasi kantor yang terletak ditengah kota Jababeka yang lokasinya 
dekat dengan sekolah, perusahaan, perkantoran dan lembaga lainnya. Lokasi yang mudah dicari dan dijangkau oleh transportasi umum maupun transportasi pribadi. karena letak kantornya berada di tepi jalan dan juga keberadaan kantornya dapat dilihat dengan jelas. Lingkungan kantornya juga bagus untuk mengembangkan dan meningkatkan bisnis usaha. Dan karena itu kemungkinan masyarakat akan tertarik dan bergabung menjadi nasabah dan mitra bisnis di Bank BNI Syariah Kantor Cabang Pembantu (KCP) Jababeka-Cikarang akan lebih besar.

Selain dari pemilihan lokasi yang strategis dan tepat, BNI Syariah KCP Jababeka-Cikarang juga mengonsep suasana didalam kantor tempat bertransaksi secara langsung dengan nasabah sesuai dengan perkembangan dan tuntutan jaman. Yaitu dengan konsep "New Normal" yang tepat, modern dan minimalis. Hal ini dilihat dari tersedianya tempat cuci tangan disamping pintu masuk kantor Bank BNI Syariah KCP Jababeka-Cikarang, jarak antar tempat tunggu pelanggan/nasabah, adanya pembatas yang dipasang disetiap meja customer service dan teller dan juga mewajibkan karyawan dan nasabah yang datang ke BNI Syariah untuk memakai masker. Bentuk bangunannya yang terlihat sederhana namun elegan, desain ruangan yang simpel namun membawa nuansa nyaman dan modern serta pemilihan dekorasi kantor yang elegan dan modern. Sehingga diharapkan nasabah merasa nyaman dengan situasi dan kondisi kantor yang bersih, aman dan modern.

\section{4) Strategi Promosi (Promotion)}

Tujuan utama dari promosi adalah menginformasikan, mempengaruhi, membujuk serta mengingatkan masyarakat tentang Bank BNI Syariah dan memasarkan produk dan layanan yang dimilikinya, baik promosi secara langsung maupun secara tidak langsung. Strategi promosi yang dilakukan Bank BNI Syariah dalam meningkatkan pemasaran produk Layanan Payroll adalah sebagai berikut:

\section{a. Periklanan}

Media iklan adalah salah satu sarana strategi promosi yang digunakan Bank BNI Syariah
Kantor Cabang Pembantu (KCP) JababekaCikarang yang bertujuan untuk menginformasikan, mengingatkan, membujuk dan mempengaruhi minat masyarakat untuk menabung dan menjadi nasabah/mitra bisnis di BNI Syraiah. Bank BNI Syariah Kantor Cabang Pembantu (KCP) Jababeka-Cikarang menggunakan media cetak dan media elektronik dalam promosinya. Pada media cetak Bank BNI Syariah melakukan promosi periklanan melalui koran, brosur, buklet, poster dan selebaran, majalah dan pemasangan spanduk-spanduk di lokasi yang strategis. Sedangkan di media elektronik Bank BNI Syariah melakukan promosi melalui siaran, radio, televise, internet, dan media lainnya.

\section{b. Promosi Penjualan}

Selain melakukan promosi dengan media iklan, Bank BNI Syariah Kantor Cabang Pembantu (KCP) Jababeka Cikarang juga melakukan kegiatan strategi promosi dengan dengan sales promotion atau promosi penjualan. Tujuannya dari promosi ini adalah untuk meningkatkan jumlah penjualan dan jumlah nasabah. Bukan cuma itu saja mengingat Layanan Payroll adalah produk jasa dan layanan yang diberikan Bank BNI Syariah kepada para pengusaha dan institut untuk menjadikan mereka mitra bisnis agar mempermudah untuk mengelola keuangan dan menjaga keamanan data pribadi.

Oleh sebab itu, untuk menarik minat masyarakat agar menjadi nasabah dan mitra bisnis di Bank BNI Syariah maka diperlukan untuk membuat dan melakukan promosi penjualan yang tepat dan semenarik mugkin. Bank BNI Syariah Kantor Cabang Pembantu (KCP) Jababeka-Cikarang melakukan promosi penjualan agar mendapatkan dan menambah jumlah nasabah serta meningkatkan penjualan produk dengan menyediakan dan memberikan kemudahan dalam melakukan pekerjaannya dengan berbagai keunggulan yang di miliki di setiap produknya. 


\section{c. Publisitas}

Publisitas adalah salah satu kegiatan promosi yang bertujuan untuk mengajak para nasabah/masyarakat untuk melakukan kegiatan seperti kotak pers, pidato, seminar, laporan tahunan, donasi/sumbangan, sponsor, publikasi, hubungan masyarakat, majalalah prusahaan, berita, bakti sosial, pameran, serta kegiatan yang serupa di berbagai media yang bertujuan untuk meningkatkan nama/citra perusahaan dimata masyarakat. Baik secara langsung maupun secara tidak langsung. Bank BNI Syariah melakukan promosi publisitas melalui bakti sosial, workshop, seminar, laporan tahunan, media identitas, peringatan peristiwa tertentu donasi/sumbangan pameran dan publikasi. Dengan cara yang telah disebutkan tadi diharapkan masyarakat akan tertarik dan berminat menjadi nasabah dan mitra bisnis di Bank BNI Syariah khususnya pada produk jasa Layanan Payroll di Bank BNI Syariah Kantor Cabang Pembantu (KCP) JababekaCikarang.

\section{d. Penjualan Pribadi}

Di dunia perbankan secara umum penjualan pribadi dilakukan oleh semua para karyawan bank. Tidak hanya bagian marketing saja yang memiliki hak untuk melakukan penjual produk, tetapi juga semua karyawan bank berhak melakukan penjualan untuk produk yanga dimiliki bank tersebut. Mulai dari bawahan seperti security sampai atasan seperti manager atau direktur Bank BNI Syariah Kantor Cabang Pembantu (KCP) Jababeka-Cikarang berhak melakukan pemasaran produk misalnya dengan cara presentasi penjualan, pertemuan penjualan, program insentif, contoh dan penjelasan produk pada msyarakat dan cara lainnya.

5) Strategi Orang (People)

Dari hasil wawancara dengan salah satu karyawan Bank BNI Syariah Kantor Cabang Pembantu (KCP) Jababeka-Cikarang, diharuskan semua karyawan bank dituntut untuk mengetahui dan memahami dari seluruh produk dan layanan yang ada di Bank BNI Syariah Kantor Cabang Pembantu (KCP) Jababeka-Cikarang. Sehingga jika ada calon nasabah atau nasabah tetap yang datang dan bertanya kepada salah satu karyawan yang bertugas pada saat itu, karyawan tersebut dapat menjelaskan dan memberi informasi yang tepat pada nasabah yang datang.

\section{6) Strategi Proses (Process)}

Jika masyarakat tertarik mendaftar menjadi nasabah di Bank BNI Syariah, maka masyarakat perlu datang ke kantor cabang BNI Syariah terdekat untuk melakukan pendaftaran. Strategi Proses yang diterapkan BNI Syariah sangatlah mudah dan terjangkau, hanya dengan mengisi formulir pendaftaran di Bank BNI Syariah Kantor Cabang Pembantu (KCP) Jababeka-Cikarang sesuai ketentuan dan kesepakatan antara dua belah pihak yaitu, calon nasabah dan Bank BNI Syariah hanya dengan menggunakan identitas diri dalam pengisian formulir tersebut.

Proses sistem Layanan Payroll di Bank BNI Syariah Kantor Cabang Pembantu (KCP) JababekaCikarang, yang pertama nasabah harus membuka rekening di Bank BNI Syariah Kantor Cabang Pembantu (KCP) Jababeka-Cikarang terlebih dahulu yaitu rekening Giro atau rekening tabungan, biasanya rekening Giro untuk perusahaan/institut dan rekening iB Hasanah untuk karyawankaryawannya. Dan selanjutnya ada yang namanya PKS (Perjanjian Kerja Sama) untuk Layanan Payroll. Setelah PKS (Perjanjian Kerja Sama) selesai maka pihak perusahaa/institut memberikan data karyawannya berupa templet Exel. Dan nantinya bagian keuangan dari perusahaan/institut tersebut dapat menjalankan sendiri dengan persetujuan direktur untuk bisa bertransaksi.

\section{7) Strategi Bukti Fisik (Physical Evidance)}

Bukti fisik merupakan lingkungan tempat berinteraksi antara nasabah dan pihak bank dalam menyampaikan dan membeli serta menggunakan produk yang ditawarkan. Bagian dari bukti fisik termasuk seluruh aspek fasilitas fisik dari Bank BNI Syariah yang terdiri dari atribut eksterior dan interior serta bagian yang berwujud lainnya. Dilihat dari kantor yang dirancang untuk Bank BNI Syariah Kantor Cabang Pembantu (KCP) Jababeka-Cikarang terlihat menarik dan nyaman jika dilihat dari luar. 
Kemudian tempat parkir yang luas dan tidak begitu jauh dari kantor BNI Syariah KCP JababekaCikarang. Peralatan yang digunakan untuk proses transaksi disalam ruangan adalah kursi, meja, computer/laptop, AC, bulpoin kertas dan barangbarang lainnya yg mendukung dalam proses transaksi. Perlengkapan yang disediakan oleh pihak bank antara lain, tempat cuci tangan, tempat tunggu, toilet dan sejenisnya.

\section{Konsep Sistem Marketing Layanan Payroll di Bank BNI Syariah Kantor Cabang Pembantu (KCP) Jababeka-Cikarang}

Konsep dari sistem marketing Layanan Payroll di Bank BNI Syariah Kantor Cabang Pembantu (KCP) Jababeka menggunakan sistem digital (via BNIDirect). BNIDirect merupakan salah satu layanan yang dimiliki bank BNI dengan sistem digital yang ditujukan untuk membantu transaksi keuangan perusahaan. BNIDirect dan juga merupakan kanal elektronik yang disediakan Bank BNI bagi perusahaan atau institute untuk melakukan aktivitas transaksi keuangan dari rekening nasabah yang terdaftar di Bank BNI dan juga untuk mendapatkan informasi dari transaksi yang tercatat direkening perusahaan dengan lebih mudah, cepat dan aman. Kanal elektronik unggulan dari Bank BNI ini juga diharapkan sebagai layanan transaksi keuangan bisnis yang terlengkap, mulai dari urusan gaji karyawan sampai pembayaran pajak. Layanan BNIDirect ini juga sering disebut sebagai internet banking khusus perseroan dari Bank BNI yang mampu mengakomodir semua kegiatan transaksi perbankan sebagai rekening giro bisnis dengan berbagai fitur yang lengkap.

\section{Hambatan Yang dihadapi BNI Syariah dalam Marketing Layanan Payroll}

Dari hasil wawancara dengan salah satu karyawan BNI Syariah Kantor Cabang Pembantu (KCP) Jababeka-Cikarang serta analisis yang penulis lakukan dalam melakukan kegiatan pemasaran produk dan layanannya, Bank BNI Syariah mengahadapi beberapa hambatan sebagai berikut:

a. Kurangan karyawan Bank yang berpengalaman dalam memasarkan produk Layanan payroll. b. Kurangnya promosi dan penyuluhan secara langsung kepada masyarakat tentang keunggulan bank Syariah.

c. Kurangnya pemahaman masyarakat tentang sistem perbankan syariah.

d. Kurangnya penyuluhan dari pihak pemerintah tentang ekonomi Syariah.

e. Banyaknya perusahaan dari negara asing yang sudah bekerja sama den dan memiliki banknya sendiri.

\section{KESIMPULAN}

Berdasarkan hasil penelitian yang sudah penulis lakukan, dan berdasarkan uraian-uraian di BAB sebelumnya, maka dapat disimpulkan bahwa;

1) Strategi marketing yang gunakan di Bank BNI Syariah Kantor Cabang Pembantu (KCP) Jababeka-Cikarang untuk memasarkan produk Layanan Payroll ini dengan menggunakan strategi bauran pemasaran (marketing mix) dengan pendekatan " $7 \mathrm{P}$ ", yaitu:
a. Product (Produk)
b. Price (Harga)
c. Place (Tempat)
d. Promotion (Promosi)
e. People (Orang)
f. Process (Proses)
g. Physical Evidance (Bukti Fisik)

2) Konsep sistem dalam memasarkan produk jasa layanan payroll yang digunakan di Bank BNI Syariah yaitu dengan menggunakan sistem BNIDirect, yang merupakan salah satu layanan di Bank BNI Syariah yang bertujuan untuk membantu kegiatan transaksi keuangan perusahaan atau institute dan juga untuk mendapatkan informasi dari setiap transaksi yang tercatat direkening perusahaan dengan lebih mudah, cepat dan aman. Dengan syarat dan dan ketentuan yang mudah dan memberikan banyak keuntungan bagi perusahaan/institut yang menjadi mitra bisnis di Bank BNI Syariah. Dengan BNIDirect ini juga dapat mempermudah bagian keuangan untuk mengatur sendiri tanggal dan waktu penggajian (diluar tanggal dan waktu yang semestinya) 
dengan persetujuan direktur atau atasan tentunya.

3) Hambatan Yang dihadapi BNI Syariah dalam marketing Layanan Payroll:

a) Kurangnya karyawan bank yang berpengalaman dalam memasarkan produk Layanan payrol.

b) Kurangnya promosi dan penyuluhan secara langsung kepada masyarakat tentang keunggulan bank syariah.

c) Kurangnya pemahaman masyarakat tentang sistem perbankan Syariah:

1) Adanya pendapat bahwa sistem yang dimiliki perbankan syariah sama dengan sistem milik bank konvensional

2) Sistem bagi hasil yang ada di perbangkan syariah dianggap kurang menguntungkan jika dibandingkan dengan sistem bunga yang ada di perbankan konvensional.

d) Kurangnya penyuluhan dari pihak pemerintah tentang ekonomi syariah.

e) Banyaknya perusahaan dari negara asing yang sudah bekerja sama dan memiliki bank nya sendiri.

\section{DAFTAR PUSTAKA}

\section{Buku}

Abu Muhammad Dwiono Koesen Al Jambi, "Ayo ke Bank Syariah" (Jakarta: Mitra Sukses/Pustaka Ar Rayhan, 2016).

Abu Muhammad Dwiono Koesen Al Jambi, "Selamat Tinggal Bank Konvensional (Haramnya Bank Konvensional dan Utamanya Bank Syariah), (Jakarta: Pustaka Ar-rayhan, 2016).

Adiwarman A.Karim, "Bank Islam Analisis Fikih dan Keuangan", (Jakarta: PT. Raja Grafindo Persada,2006).

Agus Hermawan, "Komunikasi Pemasaran", (Jakarta: Erlangga, 2012).

Ali Hasan, SE,.MM "Marketing dan Kasus-Kasus Pilihan", (Yogyakart: CAPS, cetakan kedua 2014).
Cecep Hidayat, "Manajemen Pemasaran", (Jakarta: Badan Penerbit IPWI, 1998).

Drs. Ismail, MBA., Ak, "Perbankan Syariah" cetakan pertama, (Jakarta: Prenadamedia Group, 2011).

Dr. Muhammad Syafii Antonio, M.Ec. (NioGwang Chung), "Islamic Banking Bank Syariah. Dari Teori ke Praktik", (Jakarta: Gema Insani, 2001).

Fandy Tjiptono, Ph.D "Strategi Pemasaran edisi 4", (yogyarta: Andi Offset, 2017).

Fandy Tjiptono, Ph.D., "Strategi Pemasaran", (Yogyakarta: ANDI, 2017).

Heri Sudarsono, "Bank dan Lembaga Keuangan Syariah", (Jakarta: Ekonosia, 2003).

Husain Umar, "Strategic Manajemen In Action", (Jakarta: PT. Gramedia Pustaka Utama, 2001)

Karnaen Perwataatmadja \& Muhammad Syafi'i Antonio, "Apa dan Bagaimana Bank Islam", (Yogyakarta: Dana Bhakti Wakaf, 1992).

Kasmir, "Kewirausahaan", (Jakarta: PT. Raja Grafindo, 2006).

Kasmir, "Manajemen Perbankan", (Jakarta: PT. Raja Grafindo, 2014).

Kasmir, "Manajemen Perbankan", (Jakarta: PT. Raja Grafindo, 2015).

Kasmir, "Pemasaran Bank Edisi 1", (Jakarta: Prenada Media, 2004).

Kotler dan Amstrong Prinsip-Prinsip Pemasaran, (Jakarta: Erlangga, 2001).

Lexy J. Moleong, Metode Penelitian Kualitatif, (Bandung: PT. Remaja Rosdakarya, 2016).

A. Nur Rianto Al Arif, "Dasar-Dasar Pemasaran Syariah", (Bandung: Alfabeta, 2010).

Muhammad,",Manajemen Bank Syariah Edisi Kedua", (Yogyakarta: UPP STIM YKPN, 2018).

Panji Anoraga, "manajemen Bisnis", (Jakarta: Rineka Cipta, 2004).

Philip Kotler, "Manajemen Pemasaran Edisi Milenium 2", (Jakarta: PT. Ikrar Mandiri abadi, 2000). 
Prof. Dr. H. Ismail Nawawi, MPA., M.Si, "Fikih Muamalah Klasik dan Kontemporer. Hukum Perjanjian, Ekonomi, Bisnis, dan Sosial", (Bogor: Ghalia Indonesia, 2017).

Prof. Dr. Mts. Arief, M.M., M.B.A, C.P.M., "Pemasaran Jasa \& Kualitas Pelayanan", (Malang: Bayumedia Publishing, 2018)

Ricky W Grifin dan Ronald J.Ebert, "Business Eight Edition, Terjemahan Sita Wardani", (Jakarta: Erlangga, 2006).

Sofyan Assauri, Manajemen Pemasaran, (Jakarta: PT. Raja Grafindo Persada, 2015).

Wirdyaningsih,dkk., Bank dan Asuransi Islam di Indonesia, (Jakarta: Kencana, 2005).

Wiroso, "Jual Beli Murabahah", (Yogyakarta: UII Press, 2005).

\section{Internet}

Https://www.bni.co.id, di akses pada tanggal 29 Mei 2020 pukul 13.09 WIB.

https://www.bni.co.id, BNI-AR-2014, di akses pada tanggal 5 Juni pukul 16.03 WIB. https://www.bnisyariah.co.id, diakses pada tanggal 5 Juni 2020 pukul 21.15 WIB.

Https://Finansial.bisnis.com, diakses pada tanggal 14 Juni 2020 pukul 11.49 WIB.

Https://www.Talenta.co, Ervina, diakses pada tanggal 14 Juni 2020 pikul 14.20 WIB.

www.companyprofileBNIS2014.co.id, diakses pada tanggal 15 Juni 2020 pukul 21.10 WIB.

\section{Skripsi}

Bayu Ananta, "Implementasi Payroll Dalam Pemberian Gaji Karyawan Yang Berakad Wadi'ah Di Bank BRI Syariah KCP Purwokerto.", 2016.

Dita Afrina, "Strategi Pemasaran iB Hasanah Card Pada PT. BNI Syariah Cabang Bengkulu.", 2017.

Irsalina Nur Dini Atsari, “Analisis Terhadap Produk Payroll Studi Kasus Di Bank Syariah Mandiri Salatiga.", 2013.

Rani Maya Sari, "Analisis Faktor-Faktor yang Mempengaruhi Kepuasan Karyawan PT. bridgeston Sumatra Rubber Estate (BSRE) Kabupaten Simalungun Dalam Menggunakan BSM Electronic Payroll." 2020. 